\title{
GLASBA IN GLASBENO ŽIVLJENJE NA SLOVENSKEM V 17. STOLETJU
}

\author{
METODA KOKOLE \\ Znanstvenoraziskovalni center SAZU, Ljubljana
}

\begin{abstract}
Izvleček: Glavna naloga prispevka je ugotavljanje stanja raziskanosti glasbe in glasbenega življenja na Slovenskem v 17. stoletju. Sorazmerno dobro so obdelane tematike kot na primer glasbeni tiski in rokopisi iz časa ljubljanskega knezoškofa Tomaža Hrena, skladateljsko delo Isaaca Poscha, Gabriella Pulitija in Janeza Krstnika Dolarja, precej vemo o glasbenih ostalinah koprske stolnice in Akademiji ljubljanskih filharmonikov. Malo pa vemo o glasbi $v$ manjših, a pomembnih središčih na obrobju današnje Slovenije, na primer v Mariboru in na Ptuju. Slabo raziskano je tudi glasbeno življenje $v$ okviru redovnih in drugih verskih skupnosti, popolnoma nič pa se ne ve o pridobivanju glasbenega znanja.
\end{abstract}

Ključne besede: 17. stoletje, glasba na Slovenskem, stanje raziskav

\begin{abstract}
The main goal of this article is to present the state of research on music and musical life in Slovenia during the seventeenth centu$r y$. The topics that have been in the past covered in some detail include early seventeenth-century music prints and manuscripts from the time of Prince-Bishop of Ljubljana Tomaž Hren; the composers Isaac Posch, Gabriello Puliti, and Janez Krstnik Dolar; the musicalia of the cathedral in Koper; and the Academia Philharmonicorum Labacensium. However, at present, knowledge on music in important centers of peripheral areas such as Maribor and Ptuj is scant; musical activities within monastic and other religious centers are under-researched; and music education in this period represents a complete lacuna.
\end{abstract}

Keywords: seventeenth century, music on the territory of today's Slovenia, state of research

Vsak slovenski muzikolog, ki prebere naslov tega prispevka, bi lahko glede na kvantitativno statistiko muzikoloških besedil slovenskih avtorjev, ki so bila na to ali sorodno vsebino doslej objavljena - poleg dveh temeljnih obsežnejših del izpod peresa Dragotina Cvetka in Janeza Höflerja ${ }^{1}$ je od poznih osemdesetih let do danes izšel tudi dober ducat samo temu času oz. slogovnemu obdobju posvečenih preglednih razprav predvsem Cvetkovih učencev (Jože Sivec, Katarina Bedina, Ivan Klemenčič) in avtorice tega prispevka² -

1 Dragotin Cvetko, Zgodovina glasbene umetnosti na Slovenskem 1-3, Ljubljana, Državna založba Slovenije, 1958-1959; Janez Höfler, Glasbena umetnost pozne renesanse in baroka na Slovenskem, Ljubljana, Partizanska knjiga, 1978.

2 Jože Sivec, Podoba glasbenega baroka na Slovenskem, Obdobje baroka v slovenskem jeziku, književnosti in kulturi, ur. Aleksander Skaza in Ada Vidovič - Muha, Obdobja 9, Ljubljana, Filozofska fakulteta, 1989, str. 445-463; Jože Sivec, Glavne smeri glasbene reprodukcije v 
upravičeno pomislil, da je tematika docela obdelana in izčrpana ter da o njej ni potrebno ponovno razpravljati. Pa je res tako?

Dejstvo je sicer, da za vsakršno razpravo o glasbi na Slovenskem v časovnem razponu, kot je opredeljen v naslovu tega prispevka, torej v 17. stoletju, zagotovo še vedno, tudi v 21. stoletju, ostajata osnova in sta nepogrešljivi zgoraj omenjeni monografski deli Dragotina Cvetka, Zgodovina glasbene umetnosti na Slovenskem (predvsem del prve knjige, ki je izšla 1958, pred več kot petdesetimi leti), in Janeza Höflerja, Glasbena umetnost pozne renesanse in baroka na Slovenskem (1978). Vendar pa ju je nujno treba brati z ustrezno kritično distanco, ki jo sedaj omogoča čas, pretekel od njune objave, in seveda tudi sam razvoj slovenske muzikološke stroke, ki se je predvsem v zadnjih dveh desetletjih po zgledu evropsko-ameriških tokov usmeril po eni strani v vse specifičnejše raziskave posameznih fenomenov oz. segmentov obširnega glasbenozgodovinskega gradiva, po drugi pa so se raziskave odprle tudi v smislu vse pogostejšega vključevanja širših, tudi neglasbenih, na primer družbeno-ekonomskih vidikov.

Omenjeni temeljni deli, ki so jima konceptualno in slogovno bolj ali manj sledila tudi pozneje objavljena pregledna monografska dela Dragotina $\mathrm{Cvetka}^{3}$ in večina zgoraj omenjenih preglednih razprav, sta torej široko pregledni in dragoceni predvsem zaradi velikega števila zbranih in vsaj v muzikološki literaturi prvič objavljenih arhivskih podatkov ter zaradi svojih imenskih in predmetnih kazal, ki omogočajo hitrejše iskanje. Vendar pa je treba pri uporabi faktografskih navedkov postopati previdno in jih vsekakor preverjati.

baroku na Slovenskem, Glasbeni barok na Slovenskem in evropska glasba, ur. Ivan Klemenčič, Ljubljana, Založba ZRC, ZRC SAZU, 1997, str. 179-190; Katarina Bedina, Vprašanje periodizacije glasbenega baroka na Slovenskem, Muzikološki zbornik 27 (1991), str. 49-59; Katarina Bedina, Fenomen glasbenega baroka na Slovenskem, Muzikološki zbornik 28 (1992), str. 5-9; Katarina Bedina, Die Frage der Periodisierung des Musikbarock in Slowenien / Pitanje periodizacije glazbenog baroka u Sloveniji, The musical Baroque, Western Slavs, and the spirit of the European cultural communion, ur. Stanislav Tuksar, Muzikološki zbornici 1, Zagreb, Hrvatsko muzikološko društvo, Hrvatska akademija znanosti i umjetnosti, 1993, str. 125-138 in 273-284 (prevod); Katarina Bedina, Oblike opernega uprizarjanja v 17. stoletju in zgodnji odzivi na Slovenskem, Glasbeni barok na Slovenskem in evropska glasba, ur. Ivan Klemenčič, Ljubljana, Založba ZRC, ZRC SAZU, 1997, str. 191-202; Katarina Bedina, Das repräsentative Stilgefühl des 17. Jahrhunderts in Ljubljana, der Hauptstadt des Landes Krain, Zagreb 1094-1994. Zagreb $i$ hrvatske zemlje kao most između srednjoeuropskih i mediteranskih glazbenih kultura, ur. Stanislav Tuksar, Muzikološki zbornici 5, Zagreb, Hrvatsko muzikološko društvo, 1998, str. 97-104; Ivan Klemenčič, Slogovni razvoj glasbenega baroka na Slovenskem, Glasbeni barok na Slovenskem in evropska glasba, ur. Ivan Klemenčič, Ljubljana, Založba ZRC, ZRC SAZU, 1997, str. 27-41 (ponatis v delu: Ivan Klemenčič, Slovenska glasba v evropskem okviru, Celje, Društvo Mohorjeva družba, Celjska Mohorjeva družba, 2008, str. 73-92); Ivan Klemenčič, Musik im Zeitalter des Barock: ihre Stilentwicklung in Slowenien, Musicologica austriaca 16 (1997), str. 65-84 (prevod zgornjega); Metoda Kokole, The Baroque musical heritage of Slovenia, The Consort 51 (1995), str. 91-102; Metoda Kokole, Music in Slovenia, A history of Baroque music, George J. Buelow, Bloomington, Indiana University Press, 2004, str. 429-437 in 606-610 (opombe).

3 Cvetko je svoja dognanja povzemal tudi v vseh svojih nadaljnjih monografijah vse do zadnje, ki je izšla leta 1991: Dragotin Cvetko, Slovenska glasba v evropskem prostoru, Ljubljana, Slovenska matica, 1991. 
To je pri Cvetku včasih težko, ker je imena glasbenikov, ki nimajo arhivsko izpričanih slovenskih oblik, bolj ali manj vztrajno slovenil in zraven ni povsod navedel izvirne pisave. Tudi samo slovenjenje imen za vsako ceno je preživela praksa preteklih časov.

Klasično slogovno interpretacijo, kot jo je uvedel Cvetko in nekateri njegovi učenci, je deloma presegel že Janez Höfler, danes pa se ji svetovna muzikološka stroka v splošnem upravičeno raje izogiba, saj so vsaj v prehodnih desetletjih, npr. med 1590 in 1620 ter med 1730 in 1770, slogovne oznake zagotovo nezanesljive, če ne celo sporne. Zato je tudi naslovna opredelitev glasbenozgodovinskega obdobja tega prispevka namenoma kronološka in ne stilistična, pa čeprav bi obravnavano gradivo v tradicionalni muzikološki razpravi v glavnem sodilo v okvir t. i. »baroka na Slovenskem«.

Namen tega članka vsekakor ni zgodovinski pregled, pač pa prikaz stopnje raziskanosti posameznih vsebinskih sklopov in ohranjenega gradiva $-\mathrm{z}$ navedbo po mojem osebnem mnenju osnovne in še relevantne literature, ki jo je možno uporabljati kot osnovo za prihodnje raziskave - ter ugotavljanje morebitnih pomanjkljivosti oz. idej za nove raziskave, predvsem v smislu še večje vključenosti in primerjave s sorodnimi ali celo z obravnavanim slovenskim prostorom povezanimi glasbenimi in kulturnimi tokovi. $\mathrm{Na}$ tem mestu lahko zato že takoj ugotovim, da je pri obravnavi glasbe 17. stoletja potrebna razširitev na širše geografsko področje, ki deloma sega tudi preko današnjih političnih meja Republike Slovenije, a je v razpravi nujno zaradi zgodovinske skupne pripadnosti večjim kulturno-političnim enotam.

Taka je bila nedvomno Notranja Avstrija s svojim dvorom v sedaj avstrijskem Gradcu, pretežno slovensko prestolnico nadvojvodine Koroške, Celovcem, in z mejno Goriško grofijo z močnim slovenskim zaledjem. V uvodno navedenih pregledih je namreč vsebina morda preveč omejena na osrednjo Slovenijo, če ne kar na Ljubljano. V tokratni pregled vključujem doslej deloma raziskana »nova« področja, kot je predvsem povezava z dvorno kapelo v Gradcu, ter podajam oceno stanja v slovenskih primorskih mestih, ki so bila kljub temu, da so danes del Slovenije, doslej deležna prav tako malo ali še manj pozornosti kot s slovenskim prebivalstvom poseljena dela Štajerske in Koroške. Celo o glasbenem življenju na primer Maribora in Ptuja v obravnavanem času zasledimo v novejši literaturi le drobce, ravno toliko, da zagotovo lahko ugotovimo prisotnost te umetnosti in tako rekoč popolno neraziskanost zgodovinskih virov, ki bi bili lahko morda z njo povezani.

Okvir mojega pregleda torej niso »tokovi«, temveč logični vsebinski sklopi, ki temeljijo na bolje dokumentiranih ali raziskanih segmentih; $v$ pregledu glasbenega ustvarjanja in poustvarjanja v 17. stoletju so to predvsem: glasbeni viri in prizadevanja od približno leta 1598 do okoli 1630, kar vključuje poreformacijski čas, delo knezoškofa Tomaža Hrena, vpogled v ohranjeno gornjegrajsko glasbeno zapuščino ter neohranjeno vsebino inventarja ljubljanske stolnice; poznavanje pomena in ohranjenih glasbenih del nekaterih skladateljev, ki so s svojim delom prispevali h glasbenemu življenju na geografskem prostoru današnje Slovenije, predvsem Isaaca Poscha; pogled na obmorske kraje, predvsem sedaj že malo bolj znano glasbeno življenje v koprski stolnici v 17. stoletju ter glasbeni prispevek skladateljev Gabriella Pulitija in pozneje Antonia Tarsie; jezuitska glasbeno-dramatska prizadevanja in prve operne predstave v drugi polovici 17. stoletja; delo skladatelja Janeza Krstnika Dolarja; sumarična omemba rojstva Academie philharmonicorum Labacensium 
prav na prelomu v 18. stoletje; in nazadnje zaključno ugotavljanje manj ali zgolj deloma raziskanih področij v zgodovini glasbe na Slovenskem v 17. stoletju.

V obravnavanem obdobju je, kot že rečeno, danes slovensko ozemlje upravno sodilo v sklopa dednih notranjeavstrijskih dežel (predvsem Kranjske, deloma Koroške in Štajerske ter Goriške grofije) in Beneške republike, torej po eni strani avstrijskega in po drugi italijanskega kulturnega prostora s prestolnicama v danes avstrijskem Gradcu (predvsem pomembnem do leta 1619, ko se je edini oz. najbližji dvor preselil na Dunaj) in v Kopru. Za osrednji del slovenskega prostora je bila vsekakor pomembna prestolnica Vojvodine Kranjske, Ljubljana. Prav ta središča so določala in usmerjala glasbeno poustvarjanje, ustvarjanje, pritok in nadaljnje širjenje glasbenega repertoarja po širšem geografskem prostoru.

Poleg pomena upravnih središč pa ne gre zanemariti tudi vloge mreže verskih ustanov, na primer redovnih postojank v razmerju do svojih središč ali škofij, ter tudi - čeprav v manjši meri - večjih zasebnih plemiških domovanj kot središč predvsem posvetne in zabavne glasbene kulture. Posebnost tega prostora je bila tudi široko razširjena večjezičnost, predvsem v krogu bolj izobraženega sloja prebivalstva. Zgolj zaradi tega se je na primer tako zgodaj »udomačila« italijanska dramma per musica in tudi nabave glasbenega materiala iz italijanskih središč so lahko potekale neposredno in hitro.

Glasbena dela so v 17. stoletju v največji meri nastajala ali bila izvajana zaradi samih praktičnih potreb, pa najsi so bile te verskega ali povsem posvetnega značaja. Velja se vprašati, ob kakšnih prilikah je glasba po danes slovenskem prostoru v tem času zvenela. Morda situacija še zdaleč ni bila tako drugačna, kot bi si mislili. Šlo je za bolj ali manj redno glasbeno spremljavo nedeljskega ali prazničnega bogoslužja v večjih cerkvah, razne izvedbe duhovne in posvetne glasbe ob posebnih priložnostih oz. slavjih (nemalokrat politično-dinastijskih, ko so bile zapovedane večje slovesnosti), glasbene dogodke, ki so vsebovali mešanico obeh v poučne namene (na primer jezuitske drame), po drugi strani pa je nastajala in bila izvajana glasba za zabavo, osebno muziciranje (deloma kot del plemiškega kodeksa osnovne olike), kamor bi na primer sodila plesna glasba, pozneje tudi glasbeno-gledališke predstave. Ker takšnih prilik vendarle ni bilo tako veliko in tudi osrednjeslovenski prostor ni imel tako močnih središč, ki bi omogočala zaposlitev poklicnih skladateljev, se zdi, da so glasbeni repertoar predvsem namensko pridobivali, zagotovo pa uporabljali tudi kar tistega, ki je že bil pri roki. Le redko bi lahko rekli, da je bila kaka skladba prav »naročena«, čeprav tudi ta fenomen ni povsem zaobšel naših krajev. ${ }^{4} \mathrm{Kljub}$ zelo skromno ohranjenemu primarnemu gradivu se da sklepati na poustvarjalne možnosti in s tem tudi razložiti sedanje stanje ohranjenega in zagotovo izvajanega repertoarja.

Mejno leto, 1598, ni izbrano naključno, saj za osrednjeslovenske dežele pomeni eno izmed ključnejših prelomnic: uradno ukinitev in prepoved protestantizma in nastop najradikalnejše faze protireformacijskih ukrepov, med katerimi je bil nastop novega ljubljanskega knezoškofa Tomaža Hrena in leto pred tem prihod jezuitskega reda v Ljubljano.

41611 je bila v Ljubljani izvedena maša Raimunda Ballestre, ki bi jo za to priliko pri gostujočem skladatelju lahko naročil Tomaž Hren (J. Höfler, nav. delo, 1978, str. 17 in 131-132). Morda so bile naročene tudi plesne skladbe, za katere se je koroško in kranjsko plemstvo finančno oddolžilo skladatelju Isaacu Poschu, če navedem samo nekaj zgodnejših primerov. Glede Poscha glej op. 14-16. 
Prisilni odhod izobraženih pridigarjev, učiteljev, tudi nekaterih plemičev, »sistematično« uničevanje protestantske literature - vse to je resda pomenilo, da je na grmadah verjetno zgorela tudi kaka notna izdaja ali rokopis, v celoti pa se vendar zdi, da se je glasba sama bolj ali manj izognila hujšemu preganjanju, saj so nekatere izrazito protestantske glasbene knjige pristale v knjižnicah sedaj katoliških mecenov, predvsem seveda glasbi naklonjenega Hrena. Nekatera glasbena dela protestantskih skladateljev pa so našla svoj novi dom celo v ljubljanski stolnici. ${ }^{5}$ Knezoškof se prav tako ni izogibal nekatoliškim umetnikom, saj mu sicer ne bi leta 1618 glasbil v Gornjem Gradu popravljal v protestantski šoli vzgojeni Isaac Posch, tudi sicer omiljeni glasbenik stanovske elite na Koroškem in Kranjskem.

Eno izmed manj dokumentiranih in posledično tudi manj kompleksno in primerjalno raziskanih področij glasbene zgodovine slovenskega prostora v zgodnjem 17. stoletju predstavlja glasbeno življenje $\mathrm{v}$ okviru redovnih skupnosti. Tako rekoč nič ne vemo o glasbi, na primer, frančiškanskih redov, uršulink ali klaris ter drugih v 17. stoletju aktivnih redov, pa čeprav se v slovenskih glasbenih arhivih celo najde kakšno preživelo njim pripadajoče tiskano ali rokopisno glasbeno-liturgično ali glasbeno-pedagoško delo. Celo glasbeno delo v okviru ljubljanskega jezuitskega kolegija v prvih desetletjih njegovega delovanja po primerjalno hipotetičnih zaključkih Dragotina Cvetka in Janeza Höflerja še ni bilo deležno obsežnejše in sistematičnejše obravnave. ${ }^{6}$ Še največ vemo o glasbeno-dramatskih predstavah, pa še to védenje se nanaša na izključno neglasbene vire. ${ }^{7}$ Vsekakor bi bila dobrodošla primerjava virov ljubljanskega in graškega kolegija, ki ga je neposredno podpiral notranjeavstrijski vladar nadvojvoda Ferdinand, tudi sam predan učenec jezuitov, ki je svojo politično službo prevzel leta 1595. Graška šola je bila namreč vse do odprtja ljubljanskega kolegija tudi najbližja višja avstrijska katoliška izobraževalna ustanova za učence iz južneje ležečih slovensko govorečih dežel.

Prav Gradec in predvsem dovolj dobro raziskano glasbeno življenje v tamkajšnji dvorni glasbeni kapeli sta za oceno glasbenega življenja po vsej Notranji Avstriji, še zlasti na Kranjskem in v središčih ljubljanske škofije, zaradi osebnih povezav še posebno pomembna. Graški dvor je bil našemu prostoru najbližji posvetni dvor, na katerem so se zbirali in se po njegovem okusu zgledovali tudi sicer na Slovenskem domujoči plemiči in za potrebe katerega so nastajala številna tako cerkvena kot tudi posvetna dela najsodobnejših zvrsti. ${ }^{8}$

Na graškem dvoru je zaupne službe opravljal tudi ljubljanski knezoškof Tomaž Hren,

5 Še vedno se zdi vabljiva misel, da je tam pristal vsaj del bogate glasbene knjižnice protestantskega rektorja Adama Bohoriča, ki je bila konec 16. stoletja dalj časa ponujana v odkup deželnim stanovom.

6 Gl. siceršnjo literaturo, navedeno v op. 47, spodaj.

7 Gl. na primer pregled v monografiji Stanka Škerlja, Italijansko gledališče v Ljubljani v preteklih stoletjih, Ljubljana, SAZU, 1973, str. 20-32; v novejšem času je o tem razpravljal tudi Primož Kuret, Jesuiten Schultheater in Ljubljana, Gegenreformation und Barock in Mitteleuropa in der Slowakei, ur. Ladislav Kačic, Bratislava, Slavistický kabinet SAV, 2000, str. 147-155.

8 O tem gl. Metoda Kokole, Venetian influence on the production of early-Baroque monodic motets in the Inner-Austrian provinces, Musica e Storia 8 (2000), str. 477-507; Metoda Kokole, Zgodnja duhovna monodija v notranjeavstrijskih deželah in prispevek Isaaca Poscha, Muzikološke razprave. In memoriam Danilo Pokorn, ur. Nataša Cigoj Krstulović [...], Ljubljana, Založba ZRC, 2004, str. 27-44. 
ki je svoje dobre »zveze« očitno izkoriščal tudi za zadovoljevanje glasbenih potreb svoje škofije in lastnega estetskega užitka. Prav njemu se moramo verjetno zahvaliti za še vedno zelo zgovorne ostanke glasbenega fonda gornjegrajske šole in škofovske rezidence v Gornjem Gradu, ki jih danes hranijo v Narodni in univerzitetni knjižnici v Ljubljani, $\mathrm{v}$ njih pa se $\mathrm{v}$ malem zrcali glasba, ki je zvenela in tudi nastajala $\mathrm{v}$ kapeli in za kapelo v Gradcu. Graški dvor je imel odlične dinastične in tudi glasbene zveze z dvori po tako rekoč celi Evropi, od Španije in Italije do Poljske. Omenjene muzikalije obsegajo slabih dvajset bolj ali manj ohranjenih glasbenih tiskov ter deset rokopisnih glasbenih zbirk, ki še čakajo na podrobnejšo glasbenoanalitično ovrednotenje. ${ }^{9}$

Prav tako se kaže povezava z graško glasbeno kapelo zanimiva tudi v zvezi s sorazmerno dobro znano in dokumentirano vsebino slavnega inventarja muzikalij ljubljanske stolnice, ki je nastajal od 1620 do okoli 1628, saj vsebuje številna dela italijanskih in drugih skladateljev, ki so delovali v Gradcu. ${ }^{10}$ Poleg ključne objave celotne vsebine s transkripcijo izvirnika, ki ju je priobčil v svoji monografiji leta 1978 Janez Höfler, in podrobnega opisa izpod peresa Dragotina Cvetka, ${ }^{11}$ so bili v poznejših obdobjih obrobno obravnavani še nekateri aspekti tam zabeleženega glasbenega repertoarja. ${ }^{12}$

Tam navedeni repertoar v glavnem govori v prid tezi, da so na primer okoli leta 1620 izvajali tako starejša glasbena dela, morda kdaj v novejši preobleki (z manj glasovi ali dodanim instrumentalnim basom), kot tudi nabavljali najmodernejša. Prav ta dokument takratno glasbeno življenje slovenskega prostora dejansko uvršča med najnaprednejša $v$ širšem srednjeevropskem prostoru. Žal se doslej v slovenskih arhivih ni našlo niti eno samo od glasbenih del, ki jih navaja inventar, pa tudi sam izvirnik inventarja se je ponovno izgubil iz evidence.

Da so najsodobnejša dela, ki jih inventar navaja, na Slovenskem dejansko tudi poslušali oz. jih uporabljali, dokazuje primer skladatelja Isaaca Poscha (ok. 1591-1622/23), katerega »Musicalische taffelfreudt [...] cum Basso a 4 « je kljub svoji povsem posvetni

9 Edo Škulj, Hrenove korne knjige, Ljubljana, Družina, 2001; Edo Škulj, Škof Tomaž Hren in cerkvena glasba, Bogoslovni vestnik 52 (1992), str. 110-120. O teh knjigah razpravlja tudi Metoda Kokole, The musical repertoire cultivated on the territory of modern Slovenia (1567-c. 1620) and its possible connections with the Court Chapel in Munich, Die Münchner Hofkapelle des 16. Jahrhunderts im europäischen Kontext, ur. Theodor Göllner in Bernhold Schmid, München, Verlag der Bayerischen Akademie der Wissenschaften, Kommission bei C. H. Beck, 2006, str. 171-190; ista, Italian sacred music in the period from c. 1595 to c. 1620 - with special regard to polychoral repertoire: from Graz to today's central Slovenia (v redakciji).

${ }^{10}$ Med temi so: Giovanni Priuli, Giovanni Valentini, Pietro Antonio Bianco, Simone Gatto, Francesco Stivori, Bartolomeo Mutis, pa tudi neitalijanski tam delujoči Lambert de Sayve, Alessandro Tadei, Raimundo Ballestra, Heinrich Pfendner in Georg Poss.

${ }^{11}$ Inventarium Librorum Musicalium Ecclesiae Cathedralis Labacensis. O inventarju gl. Dragotin Cvetko, Ein unbekanntes Inventarium musicalium aus dem Jahre 1620, Kirchenmusikalisches Jahrbuch 8 (1958), str. 77-80, predvsem pa J. Höfler, nav. delo, 1978, str. 36-41 in 134-157.

${ }^{12}$ Katarina Bedina je iz seznama izluščila nekatera ključna dela najzgodnejših glasbeno-dramatskih skladb, predvsem tipa duhovnih dialogov, ki jih povezuje s hipotezo o izvedbi prav tam navedene opere Euridice Giulia Caccinija. K. Bedina, nav. delo, 1991, str. 56; K. Bedina, nav. delo, 1997, str. 193-197 (v tej zvezi gl. tudi razpravi, navedeni v op. 50, predvsem M. Kokole, nav. delo, 2006, str. 223-232). O zgodnji monodiji v inventarju gl. tudi M. Kokole, Venetian influence, nav. delo, 2000; ista, Zgodnja duhovna monodija, nav. delo, 2004. 
vsebini - plesom - našla pot do ljubljanske stolnice. Isaac Posch s svojimi glasbenimi deli zagotovo sodi med najvidnejše in najzanimivejše evropske kleinmeistre zgodnjega sedemnajstega stoletja. Rodil se je okoli leta 1591 v Kremsu na Donavi, od koder je bil kot šest- ali sedemleten deček poslan v protestantsko latinsko humanistično šolo Gymnasium poeticum v Regensburg, kjer je bil deležen odlične glasbene vzgoje. Podatke o njem lahko tam s presledki najdemo vse do jeseni leta 1606. Kje je preživljal leta med 1607 in 1614, ko se je po lastnih besedah končno bolj ali manj ustalil v Celovcu, ne vemo. Vsekakor bi lahko sklepali, da se je tudi v glasbi v tem času nadalje izpopolnjeval. V Celovcu je deloval kot organist in je $\mathrm{v}$ vlogi popravljalca glasbil in izdelovalca orgel večkrat daljša obdobja preživljal tudi na bližnjem Kranjskem in spodnjem Štajerskem. Umrl je verjetno nekje na Kranjskem ali Koroškem med 24. decembrom 1622 in 31. marcem 1623.

Med letoma 1618 in 1623 so v Nemčiji izšle tri njegove glasbene zbirke. Dve vsebujeta ansambelske instrumentalne plese, tretja pa male duhovne koncerte oz. latinske motete za enega do štiri glasove in instrumentalni bas. Vse so bile posvečene njegovim mecenom, lahko bi rekli tudi prvim uporabnikom njegove glasbe, koroškim in kranjskim plemičem. Ker je v spremnem besedilu svoje prve zbirke z naslovom Musicalische Ehrenfreudt, datiranem v Ljubljani na novega leta dan 1618, izrecno napisal, da so trojice plesov namenjene dejanskemu plesu in ne zgolj poslušanju, je le-to eden izmed redkih, a zato zelo zgovornih dokazov o tem aspektu plemiške etikete v našem prostoru, ki je šele v zadnjih dveh desetletjih našel svoje mesto v okviru slovenskih muzikoloških raziskav. ${ }^{13}$

Širše zanimiva je zbirka ansambelskih instrumentalnih plesov za izvedbe na gostijah in slavjih aristokratskih krogov, Musicalische Tafelfreudt, ki jo je leta 1621 posvetil kranjskim deželnim stanovom. V njej so skladbe, v katerih so nekatere italijanske glasbene novosti, kot so oznake za dinamiko, sicer pa so presenetljivo blizu anglo-nemškemu ansambelskemu slogu, ki ga je verjetno spoznal v delih Valentina Haussmanna. Če sta instrumentalni zbirki blizu severnemu slogu, pa je Poscheva vokalna zbirka, Harmonia concertans, ki jo je v tisk poslala njegova vdova leta 1623, po svojem značaju povsem primerljiva z deli nekaterih italijanskih sodobnikov, predvsem tistih, ki so bili povezani tudi z močno italianiziranim dvorom v Gradcu. Dela Isaaca Poscha tako v celoti predstavljajo zanimivo mešanico glasbenih elementov različnih »šol«: nemške, italijanske in posredno celo angleške, kar ga, kot rečeno, umešča med evropsko zanimive skladatelje. Hkrati pa je kot skladatelj, ki je svoja dela pisal za potrebe lokalnega plemstva, bistveno prispeval $\mathrm{k}$ razumevanju najsodobnejše glasbe $\mathrm{v}$ tem prostoru.

Življenje in glasbena dela skladatelja Isaaca Poscha so trenutno najbolje in najsodobneje obdelana tema iz glasbene dediščine slovenskega prostora v 17. stoletju. Poleg vrste člankov, predvsem pa monografije v slovenskem jeziku, ${ }^{14}$ je v lanskem letu izšel tudi revidiran in dopolnjen prevod tega dela $v$ angleškem jeziku, ki je trenutno najizčrpnejši

${ }^{13}$ O plesnem aspektu Poscheve zbirke gl. Metoda Kokole, Plesna glasba zgodnjega 17. stoletja: instrumentalne suite Isaaca Poscha, Zbornik ob jubileju Jožeta Sivca, ur. Jurij Snoj in Darja Frelih, Ljubljana, Založba ZRC, ZRC SAZU, 2000, str. 87-104, predvsem pa novejšo študijo iste avtorice, The dances of Posch's collection Musicalische Ehrenfreudt as functional music, De musica disserenda 2/2 (2006), str. 75-98.

${ }^{14}$ Metoda Kokole, Isaac Posch »diditus Eois Hesperiisque plagis - slavljen v deželah Zore in Zatona«: zgodnjebaročni skladatelj na Koroškem in Kranjskem, Ljubljana, Založba ZRC, 1999. 
in najzanesljivejši vir za morebitne nadaljnje študije ali primerjalno uporabo v najširših mednarodnih muzikoloških krogih. ${ }^{15} \mathrm{~V}$ sodobnih znanstvenokritičnih izdajah so bila $\mathrm{V}$ sodobni notaciji objavljena tudi vsa skladateljeva znana glasbena dela. ${ }^{16}$

$\mathrm{V}$ istem času, ko je Isaac Posch skladal za koroško in kranjsko elito, ki se je med Ljubljano in Gradcem navduševala nad njegovimi nekaterimi močno italianiziranimi deli in verjetno plesala po italijanskem načinu na njegovo glasbo, je ne tako daleč stran, v beneškem Kopru, v nekaterih pogledih sorodno glasbo ustvarjal skladatelj Gabriello Puliti (ok. 1580-1644), minoritski brat, doma iz Toskane. ${ }^{17}$ Tudi njegov ohranjeni glasbeni opus (vsega skupaj je med 1600 in 1635 napisal vsaj 36 del oziroma izdal toliko oštevilčenih zbirk) je v celoti (vse, kar je bilo dovolj ohranjeno) objavljen v sedmih zvezkih znanstvenokritične zbirke Monumenta artis musicae Sloveniae. ${ }^{18}$ Pulitijevo delo je bilo doslej v veliki meri tudi glasbeno analizirano in umeščeno v povsem italijansko glasbeno življenje prestolnice beneške Istre, kjer je zagotovo bival in ustvarjal v letih 1606-1609, 1614-1620 in 1622-1624. ${ }^{19}$ Ker je Puliti nekaj časa deloval tudi v danes hrvaški Istri ter v danes italijanskem Trstu in v Miljah, njegov opus preučujejo tudi hrvaški in italijanski muzikologi. ${ }^{20}$

Gabriello Puliti se je rodil ok. 1580 v Montepulcianu pri Arezzu v Toskani. Najzgodnejša dokumenta o njegovi skladateljski dejavnosti predstavljata zbirki tradicionalnih petglasnih motetov in psalmov, tiskani v letih 1600 in 1602, ko je že deloval kot

${ }^{15}$ Metoda Kokole, Isaac Posch »diditus Eois Hesperiisque plagis - praised in the lands of Dawn and Sunset«, Frankfurt [...], Peter Lang, 2009.

${ }^{16}$ Isaac Posch, Musicalische Ehrenfreudt (1618), ur. Metoda Kokole, Monumenta artis musicae Sloveniae XXX, Ljubljana, ZRC SAZU, 1996; Isaac Posch, Musicalische Tafelfreudt (1621), ur. Metoda Kokole, Monumenta artis musicae Sloveniae XXXI, Ljubljana, ZRC SAZU, 1996; Isaac Posch, Harmonia concertans (1623), ur. Metoda Kokole, Monumenta artis musicae Sloveniae XXXV, Ljubljana, ZRC SAZU, 1998; Isaac Posch, Pet motetov / Five Motets, ur. Domen Marinčič, Monumenta artis musicae Sloveniae. Supplementa 2, Ljubljana, ZRC SAZU, 2008.

${ }^{17}$ Poskus sistematičnega bio- in bibliografskega opisa v slovenskem jeziku je izšel kot uvodno besedilo k prvemu zvezku skladateljevih zbranih del. Metoda Kokole, Uvod, Gabriello Puliti, Sacri concentus (1614), Pungenti dardi spirituali (1618), ur. Metoda Kokole, Monumenta artis musicae Sloveniae XL, Ljubljana, ZRC SAZU, 2001, str. XIII-XV.

${ }^{18}$ Pulitiju so posvečeni zvezki: 40, 42, 44, 46, 48, 50 in 54. Glasbena dela, ki jih je napisal v Kopru in za potrebe koprskega glasbenega življenja, so naslednja: Gabriello Puliti, Sacri concentus (1614), Pungenti dardi spirituali (1618), ur. Metoda Kokole, Monumenta artis musicae Sloveniae XL, Ljubljana, ZRC SAZU, 2001; Gabriello Puliti, Lilia convallium (1629), Sacri accenti (1620), ur. Metoda Kokole, Monumenta artis musicae Sloveniae XLII, Ljubljana, ZRC SAZU, 2002; Gabriello Puliti, Il secondo libro delle messe (1624), ur. Ennio Stipčević, Monumenta artis musicae Sloveniae XLVIII, Ljubljana, ZRC SAZU, 2006.

${ }^{19}$ O Pulitiju gl. tudi del razprave Metoda Kokole, Sacred music in »Capo d'Istria« in the 17 th century, Barocco Padano 4, ur. Alberto Colzani [...], Contributi musicologici del Centro Ricerche dell'A.M.I.S. 16, Como, A.M.I.S., 2006, str. 225-261: 228-240.

${ }^{20}$ Ennio Stipčević, Uvodna razmatranja o umjetnosti Gabriella Pulitija, Arti musices 14 (1983), str. 33-50; isti, Gabriello Puliti, ranobarokni skladatelj u Istri, Musica incognita: Ivan Lukačić i njegova doba, Šibenik, Gradska Knjižnica Juraj Sizgorić, 1998, str. 21-42; Nikola Lovrinić, Gabriello Puliti: Sacrae cantiones (1600)-transkripcija, analiza i kontekst nastanka. Primjer zbirke moteta sjevernotalijanskoga kruga s kraja 16. stoljeća, Zagreb, 2007 (Muzička akademija Sveučilišta u Zagrebu, magistrska naloga). 
minoritski brat in organist $v$ samostanih $v$ Pontremoliju in v Piacenzi. Od januarja 1604 dalje je živel v Istri, najprej v Pulju, potem pa v Kopru, v Miljah, zopet v Kopru, v Trstu, pa spet $\mathrm{v}$ Kopru, malo $\mathrm{v}$ Labinu, ponovno $\mathrm{v}$ Kopru in nazadnje $\mathrm{v}$ Trstu, kjer je verjetno leta 1644 tudi umrl.

Prav leta, ko je bil stolni organist v Kopru, so bila njegovo najplodnejše obdobje skladateljskega ustvarjanja. Leta 1614 je v Benetkah izdal dve zbirki duhovne glasbe, dvajset psalmov v zbirki Psalmodia vespertina ${ }^{21}$ in zbirko motetov za enega do tri glasove in basso continuo, ki je v nekaterih pogledih sorodna Poschevi nekoliko poznejši zgoraj omenjeni zbirki. ${ }^{22}$ Psalmodia vespertina je bila natisnjena kot skladateljev opus 13 , kar pomeni, da je danes več kot polovica njegovih zgodnejših del izgubljena. Čeprav je zbirka le delno ohranjena, predstavlja dragocen dokument za zgodovino glasbe na Slovenskem, saj dokazuje Pulitijeve zveze in stike z bližnjimi notranjeavstrijskimi deželami, predvsem s Kranjsko. Puliti je svoje psalme po nasvetu tržaškega škofa Ursina Bertija naslovil na opata cistercijanskega samostana v Stični in svetovalca nadvojvode Ferdinanda, Jakoba Reinprechta. Ta je slovel kot goreč protireformator in poleg ljubljanskega škofa Tomaža Hrena najradodarnejši pospeševalec umetnosti na Kranjskem. Da bi na opata, ki mu je posvetil svoje delo, napravil vtis, je ustvaril dela za štiri enake glasove in orgelski continuo, kar je ustrezalo potrebam samostanskega bogoslužja. ${ }^{23}$

$\mathrm{Z}$ notranjeavstrijskimi deželami ga povezuje tudi zbirka madrigalov s posvetilom nadvojvodi Ferdinandu leta $1609^{24}$ in ne nazadnje velja omeniti, da so bile kar štiri Pulitijeve zbirke popisane v zgoraj omenjenem inventarju ljubljanske stolnice. ${ }^{25}$ Sicer pa mreža njegovih mecenov in zaščitnikov kaže na njegove cerkvene, pa tudi posvetne zveze po Istri in predvsem v Kopru. ${ }^{26}$ Tako je leta 1615 zbirko triglasnih instrumentalnih vilanel Lunario armonico perpetuo posvetil Michielu Bonzi iz Kopra, in sicer z mislijo na njegovega sina Maria, ki je bil skladateljev učenec. ${ }^{27}$ Posamezne skladbe so posvečene večjim italijanskim mestom, vključno s Koprom (Capo d'Istria Unica); v zbirki je natisnjena tudi skladba koprskega lutnjarja Celia Porra, ki opeva Verono. Mariu Bonzi

${ }^{21}$ Gabriello Puliti, Psalmodia vespertina, omnium solemnitatum totius anni iuxta ritum Sacrosanctae Romanae Ecclesiae, quatuor vocibus paribus concinenda, una cum parte organica, opera XIII, Venezia, Giacomo Vincenti, 1614 (RISM P 5651).

${ }^{22}$ Sacri concentus, unis, binis, ternisque vocibus, una cum parte organica, opera XIIII, Venezia, Giacomo Vincenti, 1614 (RISM P 5652); delo je nepopolno ohranjeno; manjka glasovni zvezek za tenor. Posvečeno je Giovanniju Turrianiju, škofu na Krku.

${ }^{23}$ Gl. tudi J. Höfler, nav. delo, 1978, str. 48.

${ }^{24}$ Gl. tudi Gabriello Puliti, Baci ardenti (1609), Armonici accenti (1621), ur. Bojan Bujić in Ennio Stipčević, Monumenta artis musicae Sloveniae XLIV, Ljubljana, ZRC SAZU, 2003.

25 »Madrigalia Gabrielis Puliti 5 Vocum; Fantasie Gabrielis Puliti a 2; Lunario Harmonico Gabrielis Puliti a 3; Missae Gabrielis Puliti cum Parti[tura] a 4«.

${ }^{26} \mathrm{O}$ socialni mreži, kot se kaže iz posvetil njegovih glasbenih del, gl. Metoda Kokole, »Servitore affetionatissimo Fra Gabriello Puliti« and the dedicatees of his published music works (16001635): from institutional commission via a search for protection to an expression of affection, De musica disserenda 3/2 (2007), str. 107-134.

${ }^{27}$ Gabriello Puliti, Lunario armonico perpetuo, calculato al meridiano, \& clima delle principali città d'Italia. A tre voci [...] Opera XVI, Venezia, Giacomo Vincenti, 1615 (RISM P 5653). Delo žal ni v celoti ohranjeno. 
je leta 1618 posvetil še instrumentalno zbirko Fantasie, scherzi et capricci za violino ali kornet solo in basso continuo.

Naslednja Pulitijeva dela v glavnem vsebujejo motete za glas in instrumentalno spremljavo: Pungenti dardi spirituali (1618), Lilia convallium in Sacri accenti (obe iz 1620) in Celesti ardori; libro quinto delli concerti a una voce sola di tenore iz leta 1622 , ki edino ni ohranjeno. Vse omenjene monodične zbirke sodijo med Pulitijeva najnaprednejša duhovna dela. Puliti je očitno res prisluhnil potrebam in željam koprske stolnice in je denimo motete zbirke Sacri accenti uredil tako, da so se prilegali prav liturgičnemu koledarju koprske škofije. Dva moteta sta bila napisana celo izrecno za največja lokalna praznika, za dan sv. Nazarija in dan sv. Cecilije, ki sta ju spremljali tudi večdnevni sejemski prireditvi z vrsto tudi glasbenih dogodkov.

Pulitijeva druga dela, več zbirk večglasnih psalmov, dve maši itd., kot konkretni primeri ohranjenega repertoarja kažejo na raznovrstnost glasbe, ki se je v prvih desetletjih 17. stoletja in še dlje tudi dejansko slišala, pa ne samo v Kopru, temveč, kot kaže ljubljanski inventar, tudi drugod po slovenskem ozemlju. Gre torej za dela v novem, t. i. baročnem slogu, torej s spremljavo instrumentov, predvsem orgel, pozneje tudi tako rekoč obveznih dveh violin in še kakega basovskega godala, hkrati pa tudi za večglasna dela a cappella po starejših modelih, a vendarle s sodobnejšim glasbenim jezikom. Glasbena dela za zbor, soliste in glasbila so, glede na število ohranjenih partov in druge podatke, izvajali le ob slovesnejših priložnostih in s pomočjo najetih, tudi »uvoženih « glasbenikov.

O glasbenem življenju in skladateljih tedaj beneških predelov današnje Slovenije Dragotin Cvetko ni pisal, ${ }^{28}$ pač pa jim je sorazmerno veliko prostora v svoji monografiji namenil Janez Höfler, ki je tudi prvi raziskoval in deloma popisoval glasbene vire danes slovenskih primorskih mest. Ti so za razliko od osrednjeslovenskega prostora veliko bolje ohranjeni, predvsem kar se tiče rokopisnega gradiva iz druge polovice 17. stoletja. ${ }^{29}$ Glede na Cvetkov odpor do italijanske dediščine naših primorskih mest seveda ne preseneča, da so se z bogatim gradivom zato upravičeno ukvarjali Italijani, predvsem tržaški muzikolog Giuseppe Radole, ki je po več desetletjih svojega raziskovalnega dela v Istri leta 1990 objavil še vedno edino samostojno znanstveno monografijo o glasbi v Kopru. ${ }^{30}$ Poleg njega je za osvetlitev posameznih tematik, ki se tičejo tudi slovenskih primorskih mest, na primer fenomena akademij, v okviru katerih je nastalo tudi marsikatero glasbeno delo, poskrbel tudi Ivano Cavallini. ${ }^{31}$

${ }^{28}$ Prav tako jih po že objavljenih izsledkih Janeza Höflerja ni vključeval v svoja pozneje pisana pregledna dela, npr. D. Cvetko, nav. delo, 1991.

29 Še posebno o Kopru gl. Janez Höfler, Glasbeniki koprske stolnice v 17. in 18. stoletju, Kronika 16 (1968), str. 140-144.

${ }^{30}$ Giuseppe Radole, La musica a Capodistria, Trst, Centro studi storico-religiosi Friuli-Venezia Giulia, 1990.

${ }^{31}$ Za razpravo o glasbi v 17. stoletju sta verjetno najpomembnejši Accademia Palladia (1567-1637; predvsem so se ukvarjali s filozofijo, etiko, poezijo itd., verjetno tudi z glasbo, saj so razni v njenem okviru pisani dialogi in razne favole skoraj zagotovo imeli tudi glasbeno spremljavo) in leta 1646 oživljena akademija, ki se je zato poimenovala Accademia dei Risorti in je nato delovala do leta 1806 (ta je bila sodeč po zadnjih raziskavah tudi pedagoška ustanova). Gl. predvsem Ivano Cavallini, Musica, cultura e spettacolo in Istria tra '500 e '600, Firence, Olschki, 1990 (posamezni segmenti). Gl. tudi Ivano Cavallini, Musica e filosofia nell'Accademia Palladiana 
Od leta 2001 se z gradivom in raziskavami glasbenega življenja v slovenskih primorskih mestih intenzivno ukvarja skupina raziskovalk in raziskovalcev na Muzikološkem inštitutu ZRC SAZU. V okviru dveh dosedanjih raziskovalnih projektov so bili na več načinov popisani tam ohranjeni glasbeni tiski in rokopisi. ${ }^{32}$ Najbogatejši je z rokopisi iz 17. stoletja Škofijski arhiv Koper, katerega vsi viri so sedaj popisani v mednarodni podatkovni zbirki RISM, serija A/II. Raziskovalni rezultati so bili javnosti predstavljeni v okviru pregledne razstave ob zaključku prvega projekta, ko je izšel tudi poseben Vodnik po razstavi Glasbena dediščina slovenskih obalnih mest do 19. stoletja..$^{33}$ Glede obravnavanega obdobja so predvsem pomembna naslednja poglavja te publikacije: »Gabriello Puliti: prvi istrski monodik«, »Redki glasbeni tiski 17. stoletja«, »Ohranjene rokopisne muzikalije 17. stoletja« in »Antonio Tarsia: organist koprske stolnice in skladatelj«. Plod specifičnih raziskav popisanega gradiva je tudi nekaj objavljenih razprav, med katerimi sta vsaj dve skoraj izključno posvečeni 17. stoletju. ${ }^{34}$ Opozorilo na bogato dediščino je v zadnjem času spodbudilo tudi domačine, ki so se začeli posvečati svoji pretekli glasbeni zgodovini. Priredili so že več razstav in izdali ustrezne spremljajoče publikacije, katerih vsaj del je posvečen tudi glasbi in glasbenemu življenju v 17. stoletju. ${ }^{35}$

Med ohranjenimi rokopisnimi notnimi deli v fondu Škofijskega arhiva Koper se danes nahaja tudi 26 skladb Antonia Tarsie (1643-1722), koprskega plemiča, ki ga je od 1662 pa vse do 1710 koprska stolnica redno plačevala za službo organista. Očitno pa je

di Capodistria: Considerazioni sul dialogo »Dieci de’ Cento dubbi amorosi« (1621), Atti del Centro di ricerche storiche - Rovigno 17, Rovinj, Unione degli Italiani dell'Istria e di Fiume, Trst, Università Popolare, 1986-87, str. 195-213; isti, La diffusione del madrigale in Istria: i Casentini e Gabriello Puliti, Muzikološki zbornik 23 (1987), str. 39-69: 62-65. Gl. tudi prevode njegovih ključnih razprav v hrvaščino: Ivano Cavallini, Istarske glazbene teme i portreti od 16. do 19. stoljeća, Žminj, Čakavski sabor, 2007, str. 45-82.

${ }^{32}$ Glasbeni viri 16. do 18. stoletja s posebnim ozirom na slovenske primorske arhive (J6-3122; 1.7. 2001-30. 6. 2003) in Cerkveni glasbeni fondi slovenskih obalnih mest (J6-9544; 1. 7. 2007-30. 6. 2010). Tiskano gradivo, ki se nanaša na 17. stoletje, danes hranita arhiv cerkve sv. Jurija v Piranu in Škofijski arhiv Koper (iz fonda katedrale), v katerem je tudi večji fond rokopisnega notnega gradiva iz tega časa. Nekaj liturgičnih knjig v koralni notaciji iz tega stoletja je danes tudi v Osrednji knjižnici Srečka Vilharja, prvotno pa so bile le-te iz fondov nekaterih primorskih samostanov.

${ }^{33}$ Glasbena dediščina slovenskih obalnih mest do 19. stoletja. Vodnik po razstavi, ur. Alenka Bagarič in Metoda Kokole, Ljubljana, Znanstvenoraziskovalni center SAZU, Založba ZRC, 2003.

${ }^{34}$ M. Kokole, Sacred music in »Capo d'Istria«, nav. delo., 2006; ista, Sacred works by G. A. Rigatti and other Venetian composers in the context of musical life in Koper in the 17th century, Early music. Context and ideas II, Krakov, Institute of Musicology, Jagiellonian University, 2008, str. 198-227.

${ }^{35}$ Obe v nadaljevanju navedeni publikaciji sta v celoti dvojezični, z besedili v slovenskem in italijanskem jeziku. Glasbeno življenje v slovenskih obalnih mestih do 19. stoletja. Zbornik prispevkov in popis eksponatov, ur. Vlasta Beltram, Koper, Pokrajinski muzej, 2006 (pomembna sta predvsem prispevka Vlaste Beltram in Helene Gardina, ki vsebujeta tudi nekaj prej neobjavljenih novih podatkov); Darja Koter, Musica coelestis et musica profana. Glasbeni motivi v likovni dediščini od severne Istre do Vremske doline, Koper, Pokrajinski muzej, 2008. Obravnavanemu obdobju je posvečen tudi del diplomske naloge Helene Gardina, Glasbeno življenje v Kopru v času Beneške republike, Ljubljana, 2007 (Univerza v Ljubljani, Filozofska fakulteta, diplomska naloga). 
v stolnici opravljal še vrsto drugih funkcij in je nasploh skrbel za glasbo v tej ustanovi, kjer je to skoraj štirideset let pred njim počel Gabriello Puliti. Prav iz stolničnih knjig izdatkov, ki so glavni vir za dosedanje rekonstrukcije Tarsieve biografije, je znana tudi vrsta imen drugih glasbenikov, zaslužnih za glasbeno življenje v Kopru, ki je sicer zaradi kuge v 30. letih začasno zamrlo, a je pozneje, sredi stoletja zopet oživelo. Med povsem neznanimi glasbeniki, ki sta jih prva odkrivala Janez Höfler in Giuseppe Radole, ${ }^{36}$ sta bila $\mathrm{v}$ zadnjih letih v okviru projektnih raziskav identificirana še dva kapelnika, ki ju na neki način lahko povezujemo tudi z ohranjeno glasbo, in sicer oba člana koprskega servitskega reda: Antonio Julii iz Padove, delujoč v tridesetih letih, in Filippo Campagna iz osemdesetih let 17. stoletja. ${ }^{37}$ Prav glasbene aktivnosti posameznih cerkvenih redov v 17. stoletju sodijo med zelo malo raziskane ali celo neraziskane teme, čeprav, kot kažeta navedena primera, govorijo najdeni drobci informacij v prid hipotezi, da so bili redovi - ne samo jezuitski - še kako pomembni za celotno glasbeno življenje, ne le v Kopru, temveč po vsem ozemlju današnje Slovenije.

Primarno glasbeno gradivo iz 17. stoletja (okoli 200 glasbenih del, predvsem iz druge polovice stoletja), ki je ohranjeno v Kopru, je sicer popisano, a ne v celoti raziskano, in zato omogoča vrsto nadaljnjih študij, ki bodo lahko osvetlile podrobnosti tam izvajane glasbe, njenega značaja, povezav z večjimi italijanskimi glasbenimi središči in glasbeniki ter še kaj. Kot primer usmerjene študije je bil raziskan večji fond 29 rokopisnih prepisov skladb (12 mašnih stavkov, 10 psalmov in 7 motetov in antifon) ter dveh glasbenih tiskov pomembnega beneškega skladatelja Giovannija Antonia Rigattija, ki je bil s Koprom povezan tudi preko posvetila ponatisa ene od svojih zbirk. ${ }^{38} 11$ skladb ni bilo mogoče identificirati z Rigattijevimi deli, ki so izšla v njegovih tiskanih knjigah, in gre morda celo za unikate. Analiza notnega gradiva je razkrila tipe izvajane glasbe, izvajalske možnosti kapele in način dela v kapeli. Prepisovalcev je bilo vsega skupaj sedem in njihove rokopise lahko datiramo v čas zadnjih treh do štirih desetletij 17. stoletja. Zelo povedno je, da so po potrebi izvirnike tudi prirejali, na primer tako, da so zmanjšali število glasov, če ni bilo dovolj pevcev, ali pa opustili instrumentalno spremljavo (na primer violini).

Eden od prepisovalcev Rigattijevih skladb ali vsaj določenih partov je bil tudi že omenjeni Antonio Tarsia, ki se je s prepisovanjem velikega števila del očitno tudi sam učil ali vsaj izpopolnjeval svoje glasbeno znanje, in to do take mere, da je nato tudi sam skladal v podobnem načinu. ${ }^{39}$ Ime Antonio Tarsia je bilo do leta 1965, ko ga je odkril Giuseppe Radole, ${ }^{40}$ povsem neznano. Od slovenskih muzikologov ga je najpodrobneje

${ }^{36}$ J. Höfler, Glasbeniki koprske stolnice, nav. delo, 1968, str. 140-144.

${ }^{37}$ Prej spregledani podatki o obeh se nahajajo v omenjenih računskih knjigah, poleg tega pa sta obe imeni neposredno povezani z nekaterimi glasbenimi tiski iz 17. stoletja, ki so še danes ohranjeni v Kopru. O Antoniu iz Padove gl. delo, navedeno v opombi 34.

${ }^{38}$ M. Kokole, Sacred works by G. A. Rigatti, nav. delo, 2008, str. 198-227.

${ }^{39} \mathrm{O}$ tem nastaja razprava na podlagi prispevka z naslovom A largely self-taught composer Antonio Tarsia and his »teachers«: G. A. Rigatti, G. Legrenzi, Th. Orgiani, N. Monferrato, G. B. Bassani and others, ki ga je avtorica besedila predstavila leta 2009 na muzikološkem znanstvenem sestanku v Milanu.

${ }^{40}$ Giuseppe Radole, Musica e musicisti in Istria nel Cinque e Seicento, Atti e memorie della Società istriana di archeologia e storia patria 65 (1965), str. 147-214 (Tarsia na str. 195). 
obravnaval Janez Höfler v poznih šestdesetih letih. Njegove skladbe, predvsem motetne, je tudi podrobneje analiziral. ${ }^{41}$

Nato je Tarsia za celih dvajset let utonil v pozabo, dokler ni Radole leta $1990 \mathrm{v}$ dodatku svoje knjige o glasbi v Kopru objavil svojo transkripcijo in obsežno analizo skladateljevega najzgodnejšega dela, duhovnega dialoga med angelom in človekom iz leta $1660 .{ }^{42}$ Koprčani so se svojega rojaka spomnili predvsem leta 1993, ob 350. obletnici njegovega rojstva. Posvetili so mu znanstveno srečanje, katerega rezultat je bila vrsta objav tako biografskih kot tudi analitičnih razprav, ki so osvetlile življenje, delo in čas, v katerem je ustvarjal. ${ }^{43}$ V letih 1992-1993 je Milko Bizjak v samozaložbi izdal svoje transkripcije večine skladateljevih del. ${ }^{44}$ Šele leta 2006 je skladatelj dobil svoje geslo v eni izmed svetovnih glasbenih enciklopedij. ${ }^{45}$

Tarsia je dejansko pisal podobne skladbe, kot jih je tudi prepisoval. V njegovem opusu, ki je nastajal med 1660 in 1718, je 6 mašnih stavkov, 11 psalmov, 3 responsorialni spevi, 1 magnifikat, 10 motetov oz. antifon ter 1 dialog. Kljub veliki pozornosti, ki jo je bil skladatelj deležen leta 1993, pa niti njegovo življenje, predvsem tisto izven katedrale, niti njegov opus še nista povsem ovrednotena. Zagotovo bi si kot glavni tvorec in duša glasbenega življenja v koprski katedrali zaslužil monografsko obravnavo, kjer bi bile njegove skladbe analizirane v primerjavi s tistimi, ki so mu služile za zgled, in tistimi, ki so v tem času nastajale po Italiji; tudi nove znanstvenokritične izdaje vsaj najboljših kompozicij bi bile zelo dobrodošle.

Cerkveno glasbeno življenje v Kopru v 17. stoletju je prav zaradi Tarsieve glasbene zapuščine - ta je poleg njegovih lastnih skladb obsegala tudi glasbeni arhiv vseh del, ki jih je hranila stolnica, in ki se je skoraj po čudežu ohranil do danes - sorazmerno dobro znano in ga vsekakor lahko apliciramo tudi na glasbeno delovanje osrednjih ustanov, kot je bila na primer ljubljanska stolnica in druge, od katerih pa žal nimamo nobenih materialnih glasbenih ostalin iz obravnavanega časa, le sekundarne beležke, popise itd.

Veliko težja je rekonstrukcija posvetnega glasbenega življenja, saj se v Sloveniji ni ohranilo skorajda nič glasbenih ostalin, zato o tem zaenkrat lahko sklepamo le na podlagi fragmentarnih beležk v sekundarnem arhivskem gradivu, kjer se omenjajo na primer glasbila, instrumentalisti ali pa priložnosti, ob katerih so muzicirali. Pri rekonstrukciji si seveda pomagamo tudi z nekaterimi glasbenimi tiski, ki so nastali na tem prostoru ali za

${ }^{41}$ J. Höfler, Glasbeniki koprske stolnice, nav. delo, 1968, str. 142-143; Janez Höfler, Motetske kompozicije Antonia Tarsie, Zvuk 83 (1968), str. 163-168.

${ }^{42}$ G. Radole, nav. delo, 1990, str. 49-55.

${ }^{43}$ Gl. v celoti dvojezični zbornik Antonio Tarsia, 1643-1722, 350 let / anni, ur. Salvator Žitko, Koper, Izvršni svet Skupščine občine Koper, 1993. Prispevki so bili ponatisnjeni v 30. letniku Muzikološkega zbornika leta 1994, kjer so bila dodana še tri prej neobjavljena besedila. Leta 1999 je ponovno izšla še revidirana razprava Tomaža Faganela, Skladateljska zapuščina glasbenika iz Kopra Antonia Tarsie, Zbornik radova s Prvog međunarodnog muzikološkog skupa U znaku Carlotte Grisi, ur. Ivana Paula Gortan-Carlin, Novigrad, Pučko otvoreno učilište, 1999, str. 45-58.

${ }^{44}$ Musica sacra Slovenica 4-11, 13-15, 17, 31-36, 38, ur. Milko Bizjak, Ljubljana, Edition Bizjak, 1992-1993.

${ }^{45}$ Metoda Kokole, Tarsia, Antonio, Nazario, Die Musik in Geschichte und Gegenwart. Personenteil 16, Kassel [...], Bärenreiter, 2006, stolp. 519-520. 
ta prostor, a niso ohranjeni v slovenskih arhivih, na primer posvetna dela Isaaca Poscha in Gabriella Pulitija, ali pa rokopisni prepisi baletov in sonat Janeza Krstnika Dolarja.

Vsekakor iz zbranih podatkov vemo, da je bila tudi posvetna glasba vsaj tako dobro razvita in prisotna kot cerkvena. Muziciralo se je po domovih premožnejšega meščanstva in plemstva (glasbene veščine so še vedno sodile v njihovo obvezno osnovno izobrazbo), pa najsi je šlo za solistično igranje za lastni užitek ali skupinsko za širše stanovske kroge, kar je bilo tudi sicer eno od poslanstev na primer akademskih združenj. Le-ta so bila v krajih z beneško upravo že od 16. stoletja dalje, v Ljubljani pa je čas za tako ustanovo dozorel na prelomu v 18. stoletje. V okviru instrumentalnega muziciranja ohranjene skladbe in fragmenti kažejo na vse večjo popularnost godal, priljubljenost glasbil s tipkami, sicer pa prednjačijo skladbe plesnega značaja, ki so lahko služile za ples ali pa za glasbeno ozadje gostij in drugih slavij. ${ }^{46}$

Med posvetnimi vokalnimi deli so bili na slovenskem ozemlju prisotni madrigali oz. pesmi z instrumentalno spremljavo tipa arije, pozneje pa kantate. Žal je tudi glede tega gradivo več kot skopo; pač pa nam sekundarni viri pomagajo pri rekonstrukciji začetkov glasbeno-dramatskih predstav in sredi stoletja tudi prvih uprizoritev italijanske opere. Če so v obalnih mestih v vlogi pobudnikov zgodnejših glasbeno-dramatskih zvrsti nastopale akademije, so v zaledju in v notranjosti slovenskega etničnega ozemlja za to od začetka 17. stoletja dalje skrbeli predvsem jezuiti.

Žal o glasbi ljubljanskih jezuitov v 17. stoletju, vključno z glasbenimi vložki v šolskih igrah, vemo le to, da je obstajala, ni pa se ohranilo prav nič notnega gradiva, zgolj sekundarne beležke o glasbenikih, nekaj imen skladateljev (na primer Janez Jurij Hočevar, ki je bil glasbeni direktor jezuitskega gledališča in je napisal glasbo k vsaj petim šolskim igram, Marijan Čadež in Mihael Omersa; vsi so na prelomu stoletja pisali tudi sedaj izgubljene oratorije) in naslovov del ter namigi na priložnosti, ko se je muziciralo. ${ }^{47}$

${ }^{46}$ Tej »modi« sledimo od Poschevih zbirk iz let 1618 in 1621, Pulitijevih scherzov in fantazij oz. skladbic za eno do tri glasbila, Dolarjevih baletov in fragmenta tiska iz sedemdesetih let 17. stoletja, ki se je našel med notarskimi spisi Antonia Tarsie, do na primer skladbic, prepisanih okoli leta 1691, v rokopisu št. 272, ki ga hrani Rokopisna zbirka NUK v Ljubljani. Ne gre zanemariti tudi tovrstnega repertoarja, ki ga je v Ljubljani v svojem prodajnem katalogu leta 1678 ponujal tiskar Janez Krstnik Mayr. Gl. navedek v J. Höfler, nav. delo, 1978, str. 98-99.

${ }^{47} \mathrm{O}$ jezuitskem redu in kolegiju v Ljubljani obstajata dva zbornika, ki vsebujeta tudi krajši pregledni razpravi o glasbenih prizadevanjih: Edo Škulj, Jezuiti in slovenska cerkvena glasba, Jezuiti na Slovenskem, Redovništvo na Slovenskem 3, Ljubljana, Inštitut za zgodovino cerkve in Provincialat slovenske province Družbe Jezusove, 1992, str. 105-118; Tomaž Faganel, Glasbeno delo v ljubljanskem kolegiju: poskus prikaza ustroja in njegove vsebinske zasnove, Jezuitski kolegij v Ljubljani (1597-1773), ur. Vincenc Rajšp, Redovništvo na Slovenskem 4, Ljubljana, Zgodovinski inštitut Milka Kosa Znanstvenoraziskovalnega centra SAZU [...], 1998, str. 229-233. Gl. tudi Tomaž Faganel, Die Musiktätigkeit der Jesuiten im 17. Jahrhundert im slowenischen Raum zwischen Provinz und Metropole, Musik der geistlichen Orden in Mitteleuropa zwischen Tridentinum und Josephinismus, ur. Ladislav Kačic, Bratislava, Slavistický kabinet SAV, 1997, str. 87-93; P. Kuret, nav. delo, 2000, str. 147-155; Edo Škulj, Slowenische Jesuiten und die Kirchenmusik, Gegenreformation und Barock in Mitteleuropa in der Slowakei, ur. Ladislav Kačic, Bratislava, Slavistický kabinet SAV, 2000, str. 133-145; Tomaž Faganel, Der Einfluß der slowenischen Jesuiten auf die musikalischen Zustände in Mitteleuropa im 17. Jahrhundert, Muzikološki zbornik 40/1-2 (2004), str. 249-256. 
Prav zato se o tej temi ne da govoriti drugače kot hipotetično in v primerjavi z glasbo drugih jezuitskih ustanov po habsburških deželah, ki je bolje dokumentirana. Vsekakor bi bilo treba tudi glede sekundarnih podatkov ponovno sistematično pregledati sedaj objavljeno in prevedeno kroniko oz. letopis ljubljanskega kolegija ${ }^{48}$ in zbrano primerjati $\mathrm{z}$ najnovejšimi glasbenimi katalogi in popisi. Tudi ponovni pogled $\mathrm{v}$ ohranjene sinopse iger ne bi bil odveč.

Dovolj dobro pa so danes raziskani začetki opernih prizadevanj na Slovenskem, o čemer imamo poleg še vedno temeljnega dela Stanka Škerlja ${ }^{49}$ na razpolago tudi nekaj novejših razprav. ${ }^{50}$ Prvi dokumenti o italijanski operi so sicer sorazmerno zelo zgodnjega datuma (dva izvoda Euridice Giulia Caccinija, zabeležena v inventarju ljubljanske stolnice), prva zanesljiva izvedba pa je dokumentirana leta 1660, ob posebni priložnosti na zasebno pobudo. Sklepamo, da so na tak način izvedli tudi operno delo leta 1700, ki pa je še slabše dokumentirano, komaj zadosti, da lahko potrdimo recepcijo te glasbene zvrsti pri nas.

Skromni podatki o opernem uprizarjanju pa so nedvomno v nasprotju z več kot očitnim zanimanjem domačega plemstva za glasbeno gledališče. O tem lahko dovolj zanesljivo sklepamo po velikem številu še danes ohranjenih tiskanih besedil italijanskih oper, ki so jim ljubljanski plemiči in operni ljubitelji prisostvovali po bližnjih italijanskih in avstrijskih gledališčih, librete pa so nato ohranili v svojih knjižnicah. Danes v Ljubljani o tem priča predvsem bogata zbirka Semeniške knjižnice, v katere predhodnico so librete (nad 300 iz 17. in prve polovice 18. stoletja) darovali predvsem člani takratnih ljubljanskih akademij in ustanovitelji knjižnice. ${ }^{51}$

Precej dobro je raziskan tudi glasbeni opus slovenskega skladatelja iz Kamnika Janeza Krstnika Dolarja (1620-1673), ${ }^{52}$ ki je deloval prav v okviru jezuitskega reda, žal razen dveh krajših obdobij med 1645-1647 in 1656-1658 večinoma izven slovenskega ozemlja: v Passauu, Györu in predvsem na Dunaju, kjer je za tamkajšnje potrebe verjetno nastal

${ }^{48}$ Letopis (Historia annua Collegii Societatis Jesu Labacensis (1596-1591)) je v transkripciji in prevodu izdala založba Družina v Ljubljani v letih 2002 in 2003.

${ }^{49}$ S. Škerlj, nav. delo, str. 13-110.

${ }^{50}$ Metoda Kokole, Italijanske operne predstave pri Auerspergih sredi 17. stoletja - drobtinica k slovenskemu glasbenemu zgodovinopisju, Muzikološki zbornik 35 (1999), str. 115-129; ista, Najzgodnejše opere na Slovenskem. Od Euridice (?) do začetka delovanja stanovskega gledališča, Stoletja glasbe na Slovenskem, ur. Primož Kuret, Ljubljana, Festival, 2006, str. 223-247.

${ }^{51}$ O glasbenih virih Semeniške knjižnice na splošno gl. Marijan Smolik, Glasbeno življenje v baročni Ljubljani, Kronika 8 (1960), str. 183-193; Jurij Snoj, Glasbeni viri Semeniške knjižnice, Cerkveni glasbenik 80 (1987), str. 48-51; Metoda Kokole, Italian operas in Ljubljana in the Seventeenth and Eighteenth centuries, Il teatro musicale italiano nel Sacro Romano Impero nei secoli XVII e XVIII, ur. A. Colzani [...], Como, A.M.I.S., 1999, str. 263-291: 271-287 (s katalogom vseh libretov, urejenih po naslovih v abecednem vrstnem redu).

${ }^{52}$ O Dolarju gl. Tomaž Faganel, Dolar, Dollar, Tol(l)ar, Thollary, Joannes Baptista, Die Musik in Geschichte und Gegenwart. Personenteil 5, Kassel [...], Bärenreiter, 2001, stolp. 1198-1200, in tam navedeno literaturo; Dolarjev zbornik, ur. Edo Škulj, Knjižnica Cerkvenega glasbenika, Zbirka 5, Knjižna zbirka 15, Ljubljana, Družina, 2002; Edo Škulj, Življenjske postaje Janeza K. Dolarja, Kamniški zbornik 16 (2002), str. 141-145; Tomaž Faganel, Trije Kyrie - Dolarjev skladateljski vzorec, De musica disserenda 1/1-2 (2005), str. 29-60. 
tudi pretežni del njegovega opusa, katerega znani del je zdaj v celoti objavljen..$^{53}$ Najbrž je odveč poudarjati, da je bila njegova glasba širše znana po habsburških deželah. Pri pisanju svojih lastnih glasbenih del se je naslanjal na dela močno italianiziranega kroga skladateljev na Dunaju v sredini 17. stoletja (npr. Bertalli, Schmelzer, Kerll, Draghi in Biber), predvsem $v$ petdesetih in šestdesetih letih. Njegova duhovna dela so napisana za sestav od 4 do 16 pevskih glasov in mešani ansambel glasbil. Med njegovimi tremi mašami je ena parodična (Missa sopra la bergamasca) in ena v značilnem kolosalnem slogu za več zborov (do 32 glasov) ter 16 solistov (Missa Viennensis). Tudi instrumentalne sonate so bile verjetno namenjene izvajanju v cerkvi, med posameznimi mašnimi stavki, medtem ko so baleti sodili med razvedrilno glasbo, ki so jo igrali v seminarju.

Glasbene aktivnosti v ljubljanski stolnici v drugi polovici 17. stoletja so prav tako kot delo v jezuitskem kolegiju znane predvsem iz precej bogatih sekundarnih podatkov o tam aktivnih glasbenikih, priložnostih za njihovo muziciranje, poučevanje pevcev itd. Enako kot za jezuitski kolegij pa tudi na tem področju primanjkuje notnih ostalin, ki bi lahko potrdile sicer hipotetično sklepanje o repertoarju in njegovi kvaliteti. Z glasbo v stolnici v drugi polovici 17. stoletja se po Cvetku in Höflerju vse do zadnjega časa ni nihče sistematično ukvarjal. Stanje je deloma prevetril in posodobil Edo Škulj v razpravi, objavljeni leta 2008, ki pa se nanaša predvsem na leta priprav, načrtovanja, izgradnje, blagoslovitve in končno leta 1707 še posvetitve nove stolnice. ${ }^{54}$

Omenjena razprava se logično navezuje tudi na sočasno porajanje in nato prva leta delovanja prve glasbene ustanove na Slovenskem, celo širše, prve samo glasbi posvečene »akademije« italijanskega tipa v okviru Svetega rimskega cesarstva, ki so jo ljubljanski ustanovitelji, člani drugih ustanov podobnega značaja doma in v Italiji, poimenovali Academia Philharmonicorum Labacensium - Akademija ljubljanskih filharmonikov. Na tem mestu ta dovolj dobro raziskani tematski sklop zgolj omenjam in podajam ustrezno literaturo, ${ }^{55}$ saj širša obravnava tako vsebinsko kot tudi kronološko presega okvire moje razprave.

${ }^{53}$ Večina del je ohranjena $\mathrm{v}$ arhivskem fondu olomuškega knezoškofa Karla LiechtensteinCastelcorna v Kroměřížu, v sodobnih izdajah so izšla v zbirki Monumenta artis musicae Sloveniae: Janez Krstnik Dolar, Missa Villana, ur. Mirko Cuderman, Monumenta artis musicae Sloveniae IV, Ljubljana, SAZU, 1984 (R 1995); Janez Krstnik Dolar, Missa sopra la bergamasca, ur. Tomaž Faganel, Monumenta artis musicae Sloveniae XXII, Ljubljana, ZRC SAZU, 1992 (R 1997); Janez Krstnik Dolar, Psalmi / Psalms, ur. Tomaž Faganel, Monumenta artis musicae Sloveniae XXIII, Ljubljana, ZRC SAZU, 1993 (R 1997); Janez Krstnik Dolar, Balletti - Sonate, ur. Tomaž Faganel, Monumenta artis musicae Sloveniae XXV, Ljubljana, ZRC SAZU, 1994 (R 2004); Janez Krstnik Dolar, Missa Viennensis, ur. Uroš Lajovic, Monumenta artis musicae Sloveniae XXIX, Ljubljana, ZRC SAZU, 1996.

${ }^{54}$ Edo Škulj, Glasba ob posvetitvi stolnice, Stolnica sv. Nikolaja v Ljubljani, ur. Metod Benedik, Ljubljana, Stolna župnija sv. Nikolaja, Inštitut za zgodovino Cerkve pri Teološki fakulteti, Celje, Društvo Mohorjeva družba, 2008, str. 148-165.

${ }^{55}$ O tej gl. predvsem Dragotin Cvetko, Academia Philharmonicorum Labacensis, Ljubljana, Cankarjeva založba, 1962; Ivan Klemenčič, Slovenska filharmonija in njene predhodnice, Ljubljana, Slovenska filharmonija, 1988; Danilo Pokorn, Operozi in Academia Philharmonicorum, Academia Operosorum, ur. Kajetan Gantar, Ljubljana, SAZU, 1994, str. 125-140; Primož Kuret, Academia philharmonicorum v Ljubljani, Kronika 43 (1995), str. 19-24; Metoda Kokole, 
Naj le opozorim na dejstvo, da so bili mnogi člani te ustanove povezani tako z jezuitskim kolegijem kot tudi z ljubljansko stolnico, pri njihovih izvedbah pa so sodelovali tudi drugi tedanji poklicni glasbeniki, denimo instrumentalisti iz treh cehovskih združenj. Skrbeli so za duhovno in posvetno glasbo tako ob uradnih javnih slavjih kot tudi v zasebnih krogih. To prvo glasbeno združenje na Slovenskem je dejansko povezovalo vsa področja takratne glasbene poustvarjalnosti.

Prav omenjene cehovske glasbene formacije poklicnih glasbenikov instrumentalistov so bile v 17. stoletju bistveni element v mreži instrumentalnega glasbenega - predvsem posvetnega - poustvarjanja v javnih in tudi zasebnih krogih. O teh glasbenikih je ohranjenega veliko sekundarnega arhivskega gradiva, ki pa razen osnovnih objav za Ljubljano ${ }^{56}$ ali samo evidentiranja za Ptuj in Maribor ${ }^{57}$ še čaka na sistematične raziskave. Dobro bi bilo ponovno prevetriti podatke in iskati še nove. Zanimive bi bile tudi vzporednice s sorodnimi formacijami v Celovcu in v Gradcu, saj je bilo njihovo medsebojno sodelovanje doslej opredeljeno le hipotetično.

O instrumentalni glasbeni poustvarjalnosti v tem stoletju imamo sicer precej omemb, vendar pa je zanesljivih virov, kot bi bili na Slovenskem ohranjeni notni zapisi ali izvirna glasbila, le malo. Tudi sistematične raziskave o zgodovini posameznih instrumentov na Slovenskem so redke in pomanjkljive. Največ je verjetno znanega o orglah, o čemer sta v osemdesetih letih pisala predvsem Milko Bizjak in Edo Škulj, ${ }^{58}$ o godalih (violini) je trenutno v pripravi doktorska disertacija Maruše Zupančič s poglavjem, posvečenim 17. stoletju, ${ }^{59}$ o pihalih pa je največ sporadičnih podatkov za to obdobje doslej objavila Darja Koter, ki je tudi sicer v precejšnji meri osvetlila stanje glasbilarstva na Slovenskem v zgodnejših obdobjih, torej tudi v 17. stoletju. ${ }^{60}$

Academia Philharmonicorum Labacensium: zgledi, ustanovitev in delovanje, Historični seminar 2, ur. Oto Luthar in Vojislav Likar, Ljubljana, Založba ZRC, 1997, str. 205-222; Primož Kuret, Slovenska filharmonija = Academia philharmonicorum: 1701-2001, Ljubljana, Slovenska filharmonija, 2001, str. 13-23; gl. tudi razprave v zborniku 300 let. Academia philharmonicorum Labacensium 1701-2001, ur. Ivan Klemenčič, Ljubljana, Založba ZRC, ZRC SAZU, 2004 (predvsem razprave Ivana Klemenčiča, Metode Kokole in Eda Škulja).

${ }^{56}$ Anton Svetina, Ljubljanski mestni piskači in ljubljanski mestni godbeniki, Slovenska glasbena revija 3 (1955), str. 28-29 in 4 (1957), str. 3-5; Andrej Rijavec, Ljubljanski mestni muziki, Muzikološki zbornik 2 (1966), str. 37-51; Andrej Rijavec, Deželni trobentači na Kranjskem, Muzikološki zbornik 3 (1967), str. 32-40 (sistematično je bilo pregledano zgolj gradivo za 16. stoletje, ki je bilo objavljeno v monografiji: Andrej Rijavec, Glasbeno delo na Slovenskem v obdobju protestantizma, Ljubljana, Slovenska matica, 1967).

${ }^{57}$ Darja Koter, Glasba za pihala, izdelovanje glasbil in instrumentalna dediščina na Slovenskem v evropskem okviru, Zbornik Pokrajinskega muzeja Ptuj 1, Ptuj, Pokrajinski muzej, 2003, str. 126-137: 130; ista, Glasbeno življenje na Ptuju v 17. stoletju, Dolarjev zbornik, ur. Edo Škulj, Knjižnica Cerkvenega glasbenika, Zbirka 5, Knjižna zbirka 15, Ljubljana, Družina, 2002, str. 121-132: 130-131.

${ }^{58}$ Gl. pregledno delo Edo Škulj in Milko Bizjak, Orgle na Slovenskem, Ljubljana, Državna založba Slovenije, 1985 (in tam navedeno literaturo, predvsem članke Milka Bizjaka o baročnem obdobju); gl. tudi uvodni del članka Edo Škulj, Orgle v Ljubljanski stolnici, Ljubljana, ZRC SAZU, 1989.

${ }^{59}$ Maruša Zupančič, Razvoj violinizma na Slovenskem do začetka druge svetovne vojne (v pripravi).

${ }^{60}$ Gl. zbrane podatke v razpravi: Darja Koter, Izdelovalci glasbil na Slovenskem 1606-1918, Muzikološki zbornik 39 (2003), str. 123-152. 
Izmed ustvarjalcev, ki bi jih bilo potrebno v okviru glasbenega življenja v 17. stoletju na širšem Slovenskem vsekakor bolj natančno obravnavati in na katere je upravičeno opozoril Janez Höfler, naj omenim tržaškega skladatelja Martina Naimona, ki je deloval v Trstu, in Mateja Melisso, ki je deloval v goriškem jezuitskem kolegiju. O obeh je doslej pisal zgolj Höfler. V pričujočo razpravo namenoma niso vključeni glasbeniki, ki so bili sicer slovenskega rodu in sodijo zatorej v slovensko kulturno dediščino, a niso aktivno prispevali k lokalnemu glasbenemu življenju v 17. stoletju. Taka sta bila na primer Daniel Lagkhner, ki je bil rojen v Mariboru, a je bil v 17. stoletju aktiven na Nižjem Avstrijskem, ali pa Gabriel Plavec iz Ljubljane, ki je v prvih desetletjih 17. stoletja deloval v Mainzu.

Naj na koncu povzamem svoja razmišljanja o možnostih oziroma potrebah bodočih raziskav v zvezi z zgodovino glasbene umetnosti na Slovenskem v 17. stoletju. Ključnega pomena je še večja decentralizacija raziskav v smislu tehtnih študij v povezavi z najbližjimi večjimi središči, na primer raziskave arhivov v Mariboru in na Ptuju v navezavi na Gradec, ali pa zbiranje podatkov v goriških arhivih v povezavi s Trstom. Šele ko bomo imeli zares raziskane četudi le drobce o glasbeni poustvarjalnosti (morda celo ustvarjalnosti) manjših lokalnih središč, bomo lahko sestavili realno sliko dogajanja na celotnem slovenskem geografskem prostoru. Največji problem, to je pomanjkanje primarnih virov, ohranjenih muzikalij, bo verjetno tudi v bodoče glavna ovira za kakršno koli relevantno razpravo o glasbenoslogovnem razvoju, pa vendar bi znali raznovrstni sekundarni, predvsem arhivski podatki drugače osvetliti že znana dejstva.

Področja raziskav, ki so bila domala ali povsem prezrta, so predvsem glasbeno izobraževanje (načini pridobivanja glasbene izobrazbe na vseh ravneh), glasbene aktivnosti redovnih skupnosti in ugotavljanje mreže verskih središč oz. redovnih postojank ter njihovih morebitnih glasbenih interaktivnosti. Nekateri podatki o ostalinah v arhivih po vsej Sloveniji kažejo, da življenje v samostanih ni obsegalo le poustvarjanja duhovne glasbe za potrebe liturgičnih obredov, temveč so po samostanih izvajali tudi instrumentalno glasbo. Podatke glede redovnih skupnosti bi bilo treba iskati izven Slovenije v centralnih redovnih arhivih in v raznih kronikah, kot sta bolj znani jezuitska in uršulinska iz Ljubljane. V zvezi s posvetno (tudi instrumentalno) glasbeno dediščino bi bilo dobro tudi sistematično pregledati možnosti za morda še neodkrito lokalno mecenstvo po zgledu znanega primera Turjaških.

Nove študije ne morejo prinesti bistvenih novosti glede celotne podobe glasbene kulture na Slovenskem v 17. stoletju, lahko pa bi nekatere doslej hipotetične predpostavke bolje podprle $\mathrm{z}$ dejstvi, ali pa jih po potrebi modificirale. Zaradi dejanske nadnacionalne narave glasbene dediščine slovenskega prostora v 17. stoletju so študije in pregledi, če so objavljeni v jezikih, razumljivih širšemu krogu strokovnjakov, vsekakor tudi mednarodno zanimivi in zaželjeni. 


\section{MUSIC AND MUSICAL LIFE ON THE TERRITORY OF SLOVENIA IN THE SEVENTEENTH CENTURY}

\section{Summary}

The basis for all future reasearch into the history of music life on the territory of today's Slovenia in the $17^{\text {th }}$ century are undoubtedly the still referential monographs by Dragotin Cvetko (1958) and Janez Höfler (1978). These volumes offer abundant references to sources and have useful indices. However, due to the time that has elapsed since these books were published, their stylistic judgments in particular require some revision. Research on seventeenth-century music in recent decades has brought to light some new data and issues, particularly with regard to the composers Isaac Posch, Gabriello Puliti, Janez Krstnik Dolar, and Antonio Tarsia, as well as the earliest opera performances and especially assessments of the rich musicalia from the second half of the seventeenth century still extant in Koper.

The time period discussed in the article is from 1598, the official abolition of Protestantism, to 1701, the date that the Academia Philharmonicorum Labacensium was founded. The following key subjects are discussed briefly: Prince-Bishop Hren's music patronage, including discussion of the still-extant musicalia of his time and the assessment of the contents of the music inventory of the cathedral of Ljubljana (1620-c. 1628); the life and works of Isaac Posch and Gabriello Puliti; musical life in the Koper cathedral and musical activities of Antonio Tarsia; music and the Jesuits; music by the Slovenian composer Janez Krstnik Dolar; and secular music activities including the earliest operatic performances, the birth of the Academia Philharmonicorum in Ljubljana, and the sparse records on instrumental music from the second half of the century.

This overall reflection on the state of research especially revealed a lack of basic archival studies on music in peripheral areas of Slovenia that should be put into the context of the closest musical centers; Maribor and Ptuj, for example, should be compared to Graz, and Gorizia to Trieste. Musical activities within the network of monastic and other religious centers all over Slovenia are also under-researched. Even the better-known orders, such as the Jesuits, have not yet been thoroughly studied with regard to their various musical activities and connection with other local institutions and private individuals. Music education in this period represents a complete lacuna. 